\title{
Penerapan Pengenalan Wajah Untuk Aplikasi Absensi dengan Metode Viola Jones dan Algoritam LBPH
}

\author{
I Komang Setia Buana \\ Rekayasa Kriptografi, Politeknik Siber dan Sandi Negara, Bogor, Indonesia \\ Email: komang.setia@poltekssn.ac.id \\ Email Penulis Korespondensi: komang.setia@poltekssn.ac.id
}

\begin{abstract}
Abstrak-Wajah manusia dapat digunakan untuk melakukan identifikasi karena keunikan yang dimiliki berdasarkan parameter - parameter tertentu. Untuk melakukan pengenalan wajah, hal yang perlu dilakukan pertama kali adalah pendeteksian wajah. Penulis menggunakan metode Viola Jones untuk melakukan pendeteksian wajah. Metode Viola Jones dikenal memiliki kecepatan dan keakuratan yang tinggi karena menggabungkan beberapa konsep (Haar Features, Integral Image, AdaBoost, dan Cascade Classifier) menjadi sebuah metode utama untuk mendeteksi objek. Prinsip dari pengenalan wajah itu sendiri adalah objek wajah yang tertangkap kamera akan diolah dan dibandingkan dengan semua gambar wajah dalam kumpulan data yang sudah ada, sehingga diketahui identitas dari wajah tersebut. Salah satu penerapan pengenalan wajah adalah melakukan absensi dengan wajah individu. Dalam proses absensi tidak perlu ada interaksi kontak secara fisik antara manusia dengan device seperti sistem finger-print, sehingga dimasa pandemi COVID-19 saat ini penyebaran virus bisa dikurangi. Pada penelitian ini dibuat suatu sistem yang bisa mendeteksi, melacak serta mengenali wajah seseorang yang digunakan sebagai media verifikasi untuk absensi jam kedatangan dan kepulangan (time attendance) menggunakan metode Viola Jones dan algoritma Local Binary Pattern Histogtram (LBPH). Bahasa yang digunakan adalah python dengan library openCV. Bahasa PHP digunakan untuk antarmuka pengguna, sehingga user melakukan absensi lewat browser dengan database MySQL untuk tempat menyimpan data absensi. Hasil dari penelitian bahwa dengan menggunakan metode Viola Jones dan algoritma LBPH wajah berhasil diidentifikasi dan data tersimpan ke database yang digunakan untuk data absensi. Jarak dan kemiringan berpengaruh pada hasil pengenalan wajah. Jarak terlalu dekat sekitar $30 \mathrm{~cm}$ dari kamera, wajah tidak bisa terdeteksi. Sebaliknya posisi wajah terlalu jauh kurang lebih $200 \mathrm{~cm}$, wajah masih bisa dideteksi akan tetapi tidak bisa dikenali. Untuk tingkat kemiringan wajah sekitar $20^{\circ}$ dari tegak lurus masih bisa dikenali, akan tetapi pada derajat kemiringan sekitar kurang lebih $30^{\circ}$ posisi keatas maupun kekanan, wajah tidak bisa dideteksi.
\end{abstract}

Kata Kunci: Pengenalan Wajah, COVID-19; Absensi, Metode Viola Jones; Algoritma LBPH

Abstract-The human face can be used to assess because of its uniqueness based on certain parameters. To perform facial recognition, the first thing that needs to be done is face detection. The author uses the Viola-Jones method to detect faces. The Viola-Jones method is known to have high speed and accuracy because it combines several concepts (Haar Features, Integral Image, AdaBoost, and Cascade Classifier) into the main method for handling objects. The principle of camera face recognition itself is that the captured face object will be processed and compared with all face images in the existing data set so that the identity of the face is known. One of the applications of face recognition is to do attendance with individual faces. The attendance process does not need physical contact interactions between humans and devices such as the fingerprint system so that during the current COVID-19 pandemic, the spread of the virus can reduce. In this research, a system that can be checked and a person's face is used as a leverage medium for arrival and return attendance using the Viola-Jones method and the LBPH algorithm. The language used is python with the OpenCV library. The PHP language is used for the user interface so that users perform attendance via a browser with the MySQL database to store attendance data. The result of the research is that using the Viola-Jones method and the LBPH algorithm faces are identified and the data is stored in the database used for data attendance. Distance and slope affect the results of face recognition. The distance is too close about $30 \mathrm{~cm}$ from the camera, the face cannot be detected. Instead of face position is too far approximately $200 \mathrm{~cm}$, the face can still be detected but could not be identified. For a face tilt level of about $20^{\circ}$ from perpendicular, it can still be recognized, but at a tilt degree of about $30^{\circ}$ up or to the right, faces cannot be detected.

Keywords: Facial Recognition; COVID-19; Attendance; Viola-Jones Method; LBPH Algorithm

\section{PENDAHULUAN}

Wajah manusia dapat digunakan untuk melakukan identifikasi karena keunikan yang dimiliki berdasarkan parameter - parameter tertentu. Keunikan dan pengukuran parameter yang berbeda membantu kita mengenali orang dan dapat memisahkan antara manusia dengan manusia lainnya. Pengenalan wajah adalah teknik di mana identitas manusia dapat diidentifikasi hanya dengan menggunakan wajah seseorang. Sistem semacam itu dapat mendeteksi wajah kita secara real-time sehingga bisa terdeteksi identitas kita berdasarkan data yang sudah disimpan sebelumnya. Pendeteksian wajah tersebut bisa dilakukan dengan berbagai macam cara, salah satunya adalah dengan hanya menggunakan kamera untuk menangkap data dan data tersebut diolah dengan aplikasi. Pengolahan citra merupakan pengolahan dengan menggunakan komputer secara khusus untuk menghasilkan suatu citra yang lain. Pengolahan citra ini memiliki keterhubungan dengan Computer Vision, hanya Computer Vision dapat dikaitkan dengan akuisisi citra, pemrosesan, klasifikasi, pengakuan dan pencakupan keseluruhan, dan pengambilan keputusan yang diikuti dengan pengidentifikasian citra. Computer Vision merupakan salah satu bidang ilmu yang digunakan untuk mempelajari teknologi pengenalan wajah (Face recognition)[1].

Proses pengenalan wajah berbeda dengan pendeteksian wajah. Dalam proses pendeteksian wajah, sistem mengenali wajah dengan gambar dan menempatkan posisinya, sedangkan pada pengenalan wajah sistem 
mengenali orang tertentu. Untuk melakukan pengenalan wajah, hal yang perlu dilakukan pertama kali adalah pendeteksian wajah. Penulis menggunakan metode Viola Jones untuk melakukan pendeteksian wajah. Metode Viola Jones dikenal memiliki kecepatan dan keakuratan yang tinggi karena menggabungkan beberapa konsep (Haar Features, Integral Image, AdaBoost, dan Cascade Classifier) menjadi sebuah metode utama untuk mendeteksi objek[2][3][4]. Prinsip dari pengenalan wajah itu sendiri adalah objek wajah yang tertangkap kamera akan diolah dan dibandingkan dengan semua gambar wajah dalam kumpulan data yang sudah ada, sehingga diketahui identitas dari wajah tersebut. Sejumlah algoritma pengenalan wajah tersedia untuk mengenali wajah seperti Eigenfaces, Fisherfaces, Local Binary Pattern Histogtram (LBPH), dll. Pada penelitian ini penulis menggunakan algoritma LBPH untuk melakukan pengenalan wajah. LBPH merupakan teknik dari metode Local Binary Pattern (LBP) untuk mengubah peforma hasil pengenalan wajah. LBP adalah deskriptor tekstur yang dapat juga digunakan untuk mewakili wajah, karena gambar wajah dapat dilihat sebagai sebuah komposisi microtexture-pattern yaitu suatu operator non parametrik yang menggambarkan tata ruang lokal citra[5][6][7][8].

Penelitian pada paper [1] membuat aplikasi berbasis computer vision dengan tujuan mengimplementasikan algoritma pengenalan wajah eigenface untuk mendeteksi visual hacking. Penelitian ini menggunakan metode Viola-Jones untuk mendeteksi wajah. Hasil pengujian menunjukkan bahwa aplikasi berhasil mendeteksi ancaman visual hacking dengan waktu kecepatan deteksi wajah 2.7003 detik serta tingkat akurasi pengenalan wajah $94 \%$.

Pada paper [3] melakukan penelitian dengan mengimplementasi metode viola jones algoritma dengan menggunkan bahasa $\mathrm{C}++$. Bahwa sistem menunujukkan hasil dari rumusan fitur Haar dan Integral Image berhasil menujukan pendeteksian antara wajah dan objek lain / bukan wajah dengan baik. Pengujian sistem deteksi wajah dengan menggunakan Plugin Open CV menghasilkan akurasi dengan persntase 77,8\% wajah dan bukan wajah dengan persentase $84.2 \%$.

Pada paper [6] melakukan penelitian dengan membandingkan dua algoritma pengenalan wajah yaitu algoritma LPBH dan algoritma Eigenface dalam Mengenali Tiga Wajah Sekaligus secara Real-Time. Pengujian dilakukan pada 300 sampel citra wajah dengan empat kondisi pencahayaan yaitu siang hari dalam ruangan dan siang hari diluar ruangan. Hasil pengujian menunjukkan bahwa tingkat akurasi LBPH lebih baik dibandingkan eigenface dengan rata-rata akurasi LBPH adalah $93.54 \%$ dan eigenface adalah $63.54 \%$.

Pada paper [9] membuat aplikasi absensi berbasis raspberry pi. Penelitian ini menggunakan algoritma LBPH untuk mengenali wajah dan dibuat dengan menggunakan bahasa pemograman python dan library OpenCV di raspberry Pi 4 model B berbasis linux. Untuk desain aplikasi menggunakan aplikasi PyQt 4 serta dengan menggunakan kamera raspberry pi nightvision pada raspberry pi yang kemudian dijalankan program tersebut menggunakan aplikasi Geanny yang sudah dihubungkan dengan database MySQLite. Hasil yang didapat adalah pada pengujian mengambil data nama pada tabel dalam aplikasi telah berhasil dilakukan tetapi harus melakukan pemindahkan data yang sudah di disimpan ke tempat folder yang lain dan merubah nama dokumen secara manual. Dalam melakukan pengujian absensi pada wajah mahasiswa ternyata tidak bisa dilakukan dengan cara duduk di kursi masing-masing, hal tersebut boleh dilakukan akan tetapi layar frame pada aplikasi hanya bisa menangkap maksimal 2 orang saja.

Salah satu penerapan pengenalan wajah adalah melakukan absensi dengan wajah individu. Dalam proses absensi tidak perlu ada interaksi kontak secara fisik antara manusia dengan device seperti sistem finger-print, sehingga dimasa pandemi COVID-19 saat ini penyebaran virus bisa dikurangi. Pada penelitian ini akan dibuat suatu sistem yang bisa mendeteksi, melacak serta mengenali wajah seseorang yang digunakan sebagai media verifikasi untuk absensi jam kedatangan dan kepulangan (time attendance) menggunakan metode Viola Jones dan algoritma LBPH. Bahasa yang digunakan adalah python dengan library openCV. Bahasa PHP digunakan untuk antarmuka pengguna, sehingga user melakukan absensi lewat browser dengan database MySQL untuk tempat menyimpan data absensi[9][10].

\section{METODOLOGI PENELITIAN}

Penelitian ini menggunakan metode Viola Jones untuk melakukan deteksi wajah. Metode Viola Jones adalah salah satu metode untuk deteksi wajah dengan berdasarkan kepada klasifikasi gambar berdasarkan nilai fitur dalam sebuah citra. Salah satu manfaat penggunaan fitur secara langsung adalah fitur dapat digunakan untuk mengkodekan pengetahuan dengan data latih. Selain itu penggunaan fitur beralasan bahwa operasi fitur dianggap lebih cepat daripada klasifikasi berbasis piksel[11]. Untuk melakukan pengenalan wajah, penulis menggunakan algoritma LBPH. Algoritma LBPH merupakan satu metode yang digunakan untuk proses pengolahan fitur wajah seperti face detection dan face recognition. LBPH digunakan untuk pengolahan fitur wajah dan Haar Cascade untuk pengambilan frame wajah[12].

\subsection{Tahap Penelitian}

Tahapan penelitian pengenalan wajah untuk melakukan absensi sangat penting untuk dilakukan agar terselesainya penelitian yang dilakukan. Dengan dilakukannya tahapan-tahapan dengan terstruktur dan sistematis maka penelitian ini dapat berjalan dengan baik. 
ISSN 2614-5278 (media cetak), ISSN 2548-8368 (media online)

Available Online at https://ejurnal.stmik-budidarma.ac.id/index.php/mib DOI 10.30865/mib.v5i3.3008

Berikut merupakan tahapan-tahapan dalam membangun aplikasi absensi pada penelitian ini, yang dapat digambarkan seperti pada gambar 1 .

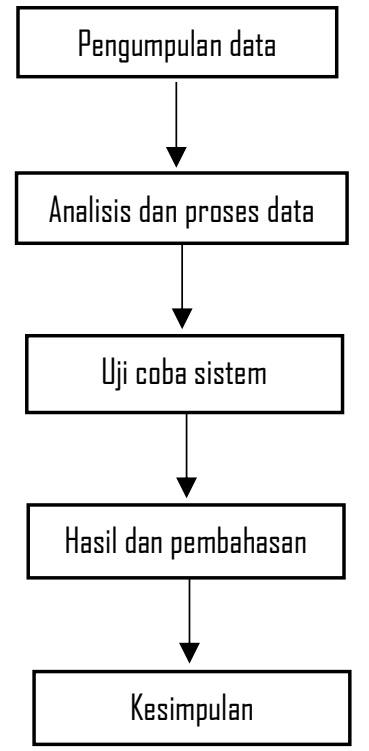

Gambar 1. Tahapan Penelitian

Gambar 1 adalah serangkaian tahapan umum dalam penelitian yang terdiri dari tahapan pengumpulan data, analisis dan proses data, uji coba sistem, hasil dan pembahasan serta kesimpulan dari penelitian.

\subsection{Pengumpulan data}

Pada tahap ini, dilakukan pengambilan data foto dengan webcam. Webcam yang digunakan pada penelitian ini bawaan dari laptop lenovo thinkpad x13 dengan resolusi HD 720p.

\subsection{Analisis dan proses data}

Pada tahap ini, dilakukan proses deteksi objek, penyimpanan data set, data training, identifikasi data pengenalan wajah dan penyimpanan data untuk keperluan absensi secara real-time. Analisis dan proses data seperti tertuang pada alur kerja sistem pada gambar 2 berikut:

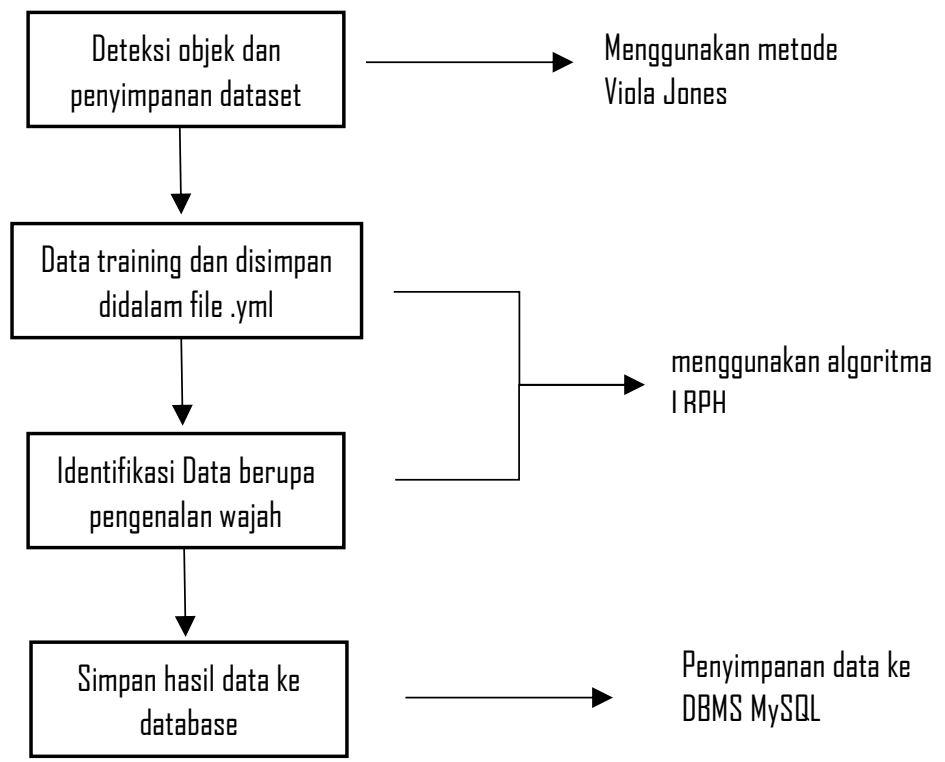

Gambar 2. Alur kerja sistem

Keterangan:

\section{A. Deteksi objek dan penyimpanan dataset}

Deteksi objek dalam penelitian ini lebih focus bagaimana menentukan wajah manusia di antara background. Objek wajah dicari menggunakan metode Viola Jones. Diagram alir metode Viola Jones terlihat pada gambar 3. 
ISSN 2614-5278 (media cetak), ISSN 2548-8368 (media online)

Available Online at https://ejurnal.stmik-budidarma.ac.id/index.php/mib DOI 10.30865/mib.v5i3.3008

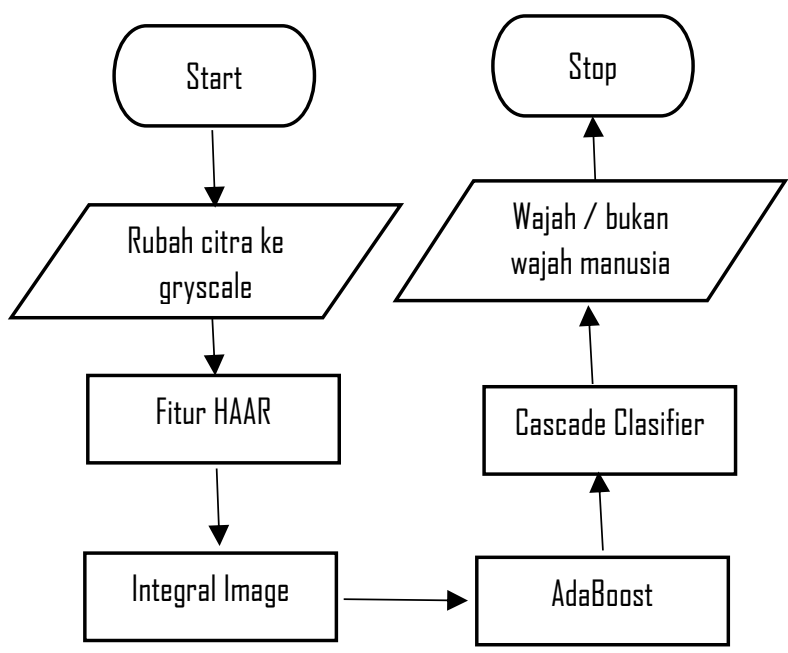

Gambar 3. Diagram alir metode Viola Jones

Seperti yang ditunjukan pada gambar 3, proses yang dilakukan adalah

1. Objek yang didapat oleh webcam akan dirubah ke grayscale terlebih dahulu

2. Dari citra gryscale akan dilakukan pembacaan fitur Haar dengan memproses citra tersebut menjadi kotakkotak untuk mendapatkan perbedaan nilai threshold dari daerah gelap dan daerah terang dari citra tersebut.

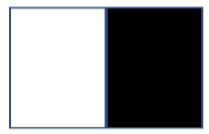

(a)

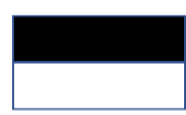

(b)

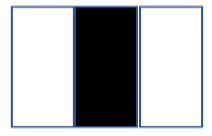

(c)

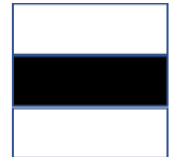

(d)

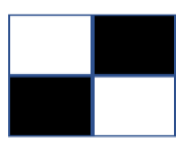

(e)

Gambar 4. Fitur Haar

Pada gambar 4 dapat dilihat bahwa terdapat 5 fitur dari kiri ke kanan, (a) dan (b) terdiri dari dua persegi panjang, (c) dan (d) terdiri dari tiga persegi panjang dan (e) terdiri dari empat persegi panjang. Cara menghitung nilai dari fitur ini adalah mengurangkan nilai pixel pada area hitam dengan pixel pada area putih. Dengan Rumus untuk mendapatkan nilai fitur sesuai dengan jumlah kotak:

B, W: Black (Hitam), White (Putih)

Dua kotak : W - B

Tiga kotak: $\mathrm{W}_{1}-\mathrm{W}_{2}-\mathrm{B}$

Empat kotak: $\left(\mathrm{W}_{1}+\mathrm{W}_{2}\right)-\left(\mathrm{B}_{1}-\mathrm{B}_{2}\right)$

Dengan begitu akan dapat ditentukan tingkat luminance dari citra yang akan dideteksi dan dapat dibedakan mana bagian citra yang mencirikan wajah manusia

3. Selanjutnya Untuk mempermudah proses penghitungan nilai fitur, metode Viola Jones menggunakan sebuah media berupa citra integral (Integral Image). Integral Image digunakan untuk menghitung nilai fitur dengan cara mengubah gambar masukan menjadi suatu representasi gambar integral. Cara perhitungannya yaitu menghitung jumlah semua piksel di dalam suatu persegi panjang dengan hanya menggunakan empat nilai secara efisien.
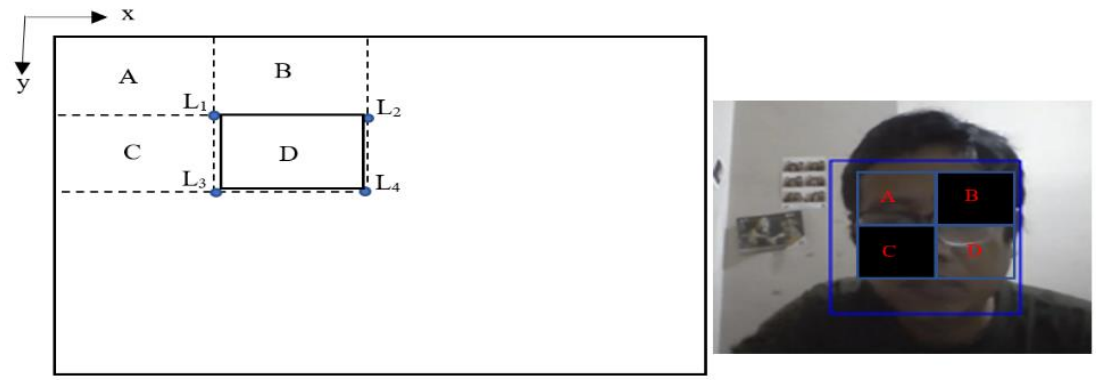

Gambar 5. Perhitungan Integral Image

Untuk perhitungannya kita melihat area segiempat dari D :

A adalah nilai integral image pada $\mathrm{L}_{1}$

$\mathrm{A}+\mathrm{B}$ adalah nilai integral image pada $\mathrm{L}_{2}$

$\mathrm{A}+\mathrm{C}$ adalah nilai integral image pada $\mathrm{L}_{3}$ 
$\mathrm{A}+\mathrm{B}+\mathrm{C}+\mathrm{D}$ adalah nilai integral image pada $\mathrm{L}_{4}$

Sehingga hasil dari $\mathrm{D}$ dapat dibuat :

$\mathrm{D}=\mathrm{L}_{4}-\left(\mathrm{L}_{2}+\mathrm{L}_{3}\right)+\mathrm{L}_{1}$

4. Kemudian untuk memilih fitur Haar yang spesifik yang akan digunakan dan untuk mengatur nilai ambangnya (threshold) digunakan sebuah metode machine learning yang disebut AdaBoost. AdaBoost menggabungkan banyak classifier lemah untuk membuat sebuah classifier kuat. Dengan menggabungkan beberapa AdaBoost classifier sebagai rangkaian filter yang cukup efisien untuk menggolongkan daerah image. Masing-masing filter adalah satu AdaBoost classifier terpisah yang terdiri classifier lemah atau satu filter Haar. Selama proses filter, bila ada salah satu filter gagal untuk melewatkan sebuah daerah citra, maka daerah itu langsung digolongkan sebagai bukan wajah. Namun ketika filter melewatkan sebuah daerah citra dan sampai melewati semua proses filter yang ada dalam rangkaian filter, maka daerah citra tersebut digolongkan sebagai wajah.

5. Tahap selanjutnya yaitu cascade classifier. Urutan filter pada cascade ditentukan oleh bobot yang diberikan AdaBoost. Filter dengan bobot paling besar diletakkan pada proses pertama kali, bertujuan untuk menghapus daerah citra bukan wajah secepat mungkin.

6. Tahapan yang terakhir adalah menampilakan objek sampel citra yang telah terdeteksi wajah ataupun bukan wajah.

Hasil dari metode Viola Jones akan disimpan ke folder di komputer sebagai dataset untuk proses pengenalan wajah. Setiap orang akan disimpan 100 gambar yang terdeteksi wajah[13][14][15].

\section{B. Data raining}

Data training menggunakan algoritma LBPH. Algoritma LBPH dapat mencari tekstur dari sebuah gambar kemudian mengambil setiap piksel dari gambar tersebut, sehingga kerapatan antar piksel dapat mengoptimalkan prediksi gambar saat dilakukan identifikasi wajah. Pada algoritma LBPH, citra yang terdapat di folder dataset akan dibagi dibagi menjadi beberapa bagian, kemudian dilakukan proses ekstraksi fitur untuk mendapatkan nilai histogram dengan mengubah setiap pixel dari citra menjadi thresholding dengan ukuran $3 \times 3$ dengan diambil satu pixel tengah untuk menjadi pembanding. Jika nilai tetangga lebih besar atau sama besar dari pixel yang menjadi pembanding dalam nilai grayscale maka akan diubah nilainya menjadi 1 dan sebaliknya jika nilai tetangga lebih kecil dari pembanding dalam nilai grayscale maka akan diubah nilai pixelnya menjadi 0 . Setelah diubah menjadi nilai biner maka akan menghasilkan deret biner yang kemudian jika diubah menjadi nilai decimal akan menghasilkan nilai baru untuk nilai tengah pixel selanjutnya, deret biner tersebut yang disebut dengan kode LBP. Hasil dari deret biner ini disimpan didalam file .yml yang akan digunakan untuk proses pengenalan wajah[16][17].

\section{Identifikasi data berupa pengenalan wajah}

Pada proses ini akan dilakukan pengenalan wajah dengan webcam. Seperti pada data training, dalam pengenalan wajah menggunakan algoritma Local Binnary Pattern Histogram (LBPH). Informasi di data training yang sudah tersimpan di file .yml akan dibandingkan dengan data real-time yang ditangkanp oleh webcam. Ketika data biner sesuai dengan data yang tersimpan di file .yml, maka identidas dari data tersebut akan di tampilkan di layar berupa nama[18].

\section{Simpan hasil data ke database}

Data identitas yang sudah teridentifikasi akan disimpan didatabase mysql yang digunakan untuk data absensi. Ketika wajah sudah dikenali maka akan langsung tersimpan di database.

\section{HASIL DAN PEMBAHASAN}

Sebagai user interface, didalam penelitian ini penulis menggunakan bahas pemrograman PHP. User interface yang penulis buat seperti gambar 6 .

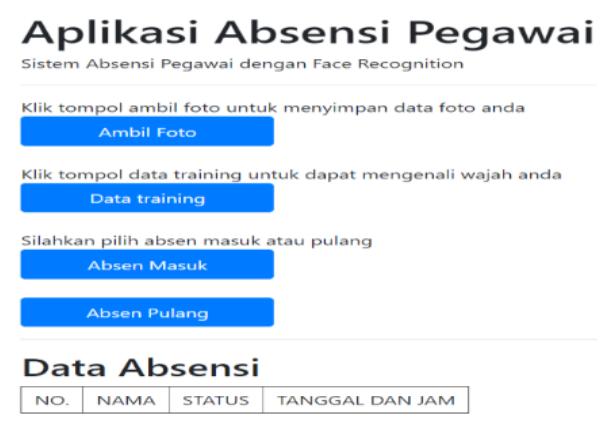

Gambar 6. User Interface Aplikasi Absensi 
JURNAL MEDIA INFORMATIKA BUDIDARMA

Volume 5, Nomor 3, Juli 2021, Page 1008-1017

ISSN 2614-5278 (media cetak), ISSN 2548-8368 (media online)

Available Online at https://ejurnal.stmik-budidarma.ac.id/index.php/mib DOI 10.30865/mib.v5i3.3008

Terdapat 4 tombol didalam user interface absensi pegawai

a) Ambil foto

Digunakan untuk deteksi objek dan menyimpan dataset

b) Data training

Digunakan untuk data training dan hasil disimpan didalam file .yml

c) Absen masuk

Digunakan untuk melakukan absensi masuk

d) Absen pulang

Digunakan untuk absensi pulang

\subsection{Hasil pada tahapan deteksi objek dan penyimpanan data ke dataset}

Untuk melakukan deteksi objek klik tombol ambil foto pada user interface pada gambar 6. Dengan menggunakan metode Viola Jones, hasil deteksi objek seperti gambar 7
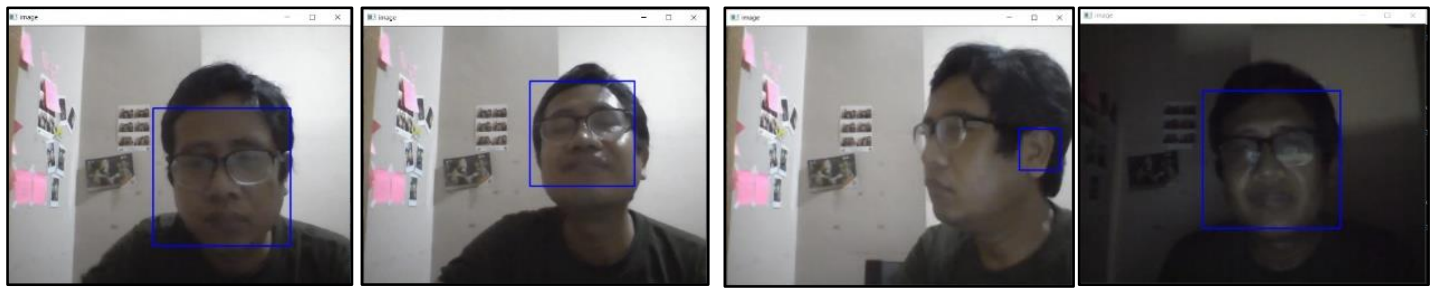

Gambar 7. Deteksi objek wajah

Ketika wajah sudah terdeteksi, maka data wajah akan tersimpan di folder dataset sebanyak 100 gambar. Ketika gambar wajah sudah tersimpan 100 gambar maka, program akan keluar. Dengan pencahayaan redup proses deteksi berhasil dilakukan kecuali posisi menghadap kesamping akan terjadi kekeliruan untuk pendeteksian objek wajah.
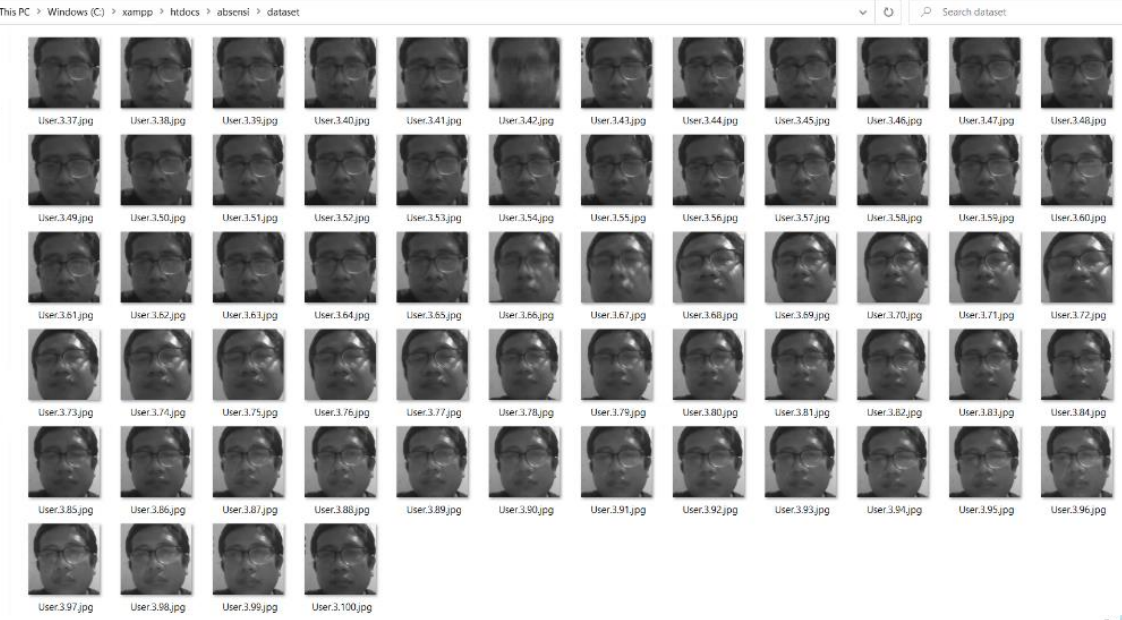

Gambar 8. Dataset wajah

\subsection{Hasil Data Training}

Untuk melakukan data training klik tombol data training pada user interface pada gambar 4. Data training menggunakan algoritma LBPH. Hasil data training disimpan kedalam file .yml, yang akan digunakan untuk proses pengenalan wajah.

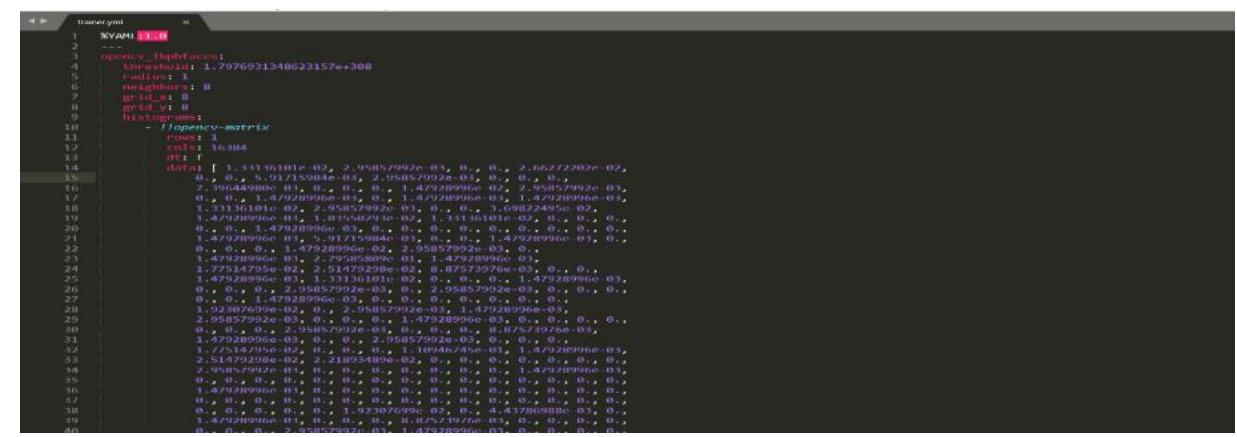

Gambar 9. Potongan hasil data training

I Komang Setia Buana, Copyright (C2021, MIB, Page 1013 Submitted: 15/05/2021; Accepted: 01/07/2021; Published: 31/07/2021 
JURNAL MEDIA INFORMATIKA BUDIDARMA

Volume 5, Nomor 3, Juli 2021, Page 1008-1017

ISSN 2614-5278 (media cetak), ISSN 2548-8368 (media online)

Available Online at https://ejurnal.stmik-budidarma.ac.id/index.php/mib DOI 10.30865/mib.v5i3.3008

\subsection{Hasil Pengenalan Wajah dan Penyimpanan Data Absensi}

Untuk melakukan absen masuk atau pulang klik tombol absen masuk atau absen pulang pada user interface pada gambar 10 .
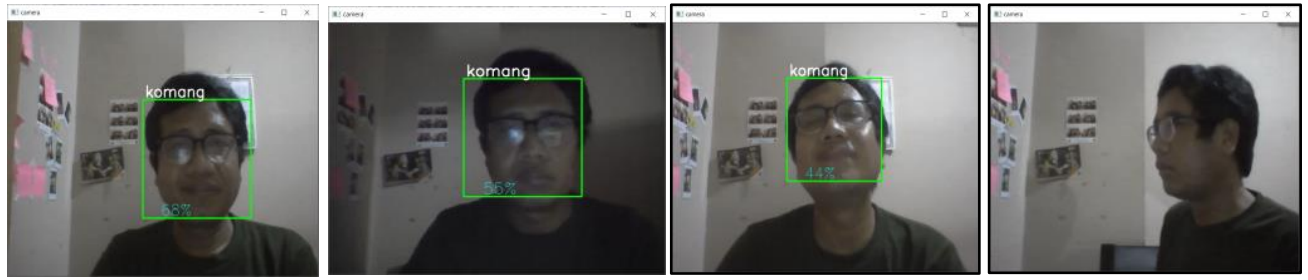

Gambar 10. Pengenalan wajah

Setelah wajah dikenali maka data absen akan tersimpan ke database. Dengan pencahayaan redup masih bisa mengenali wajah, kecuali posisi menghadap kesamping.

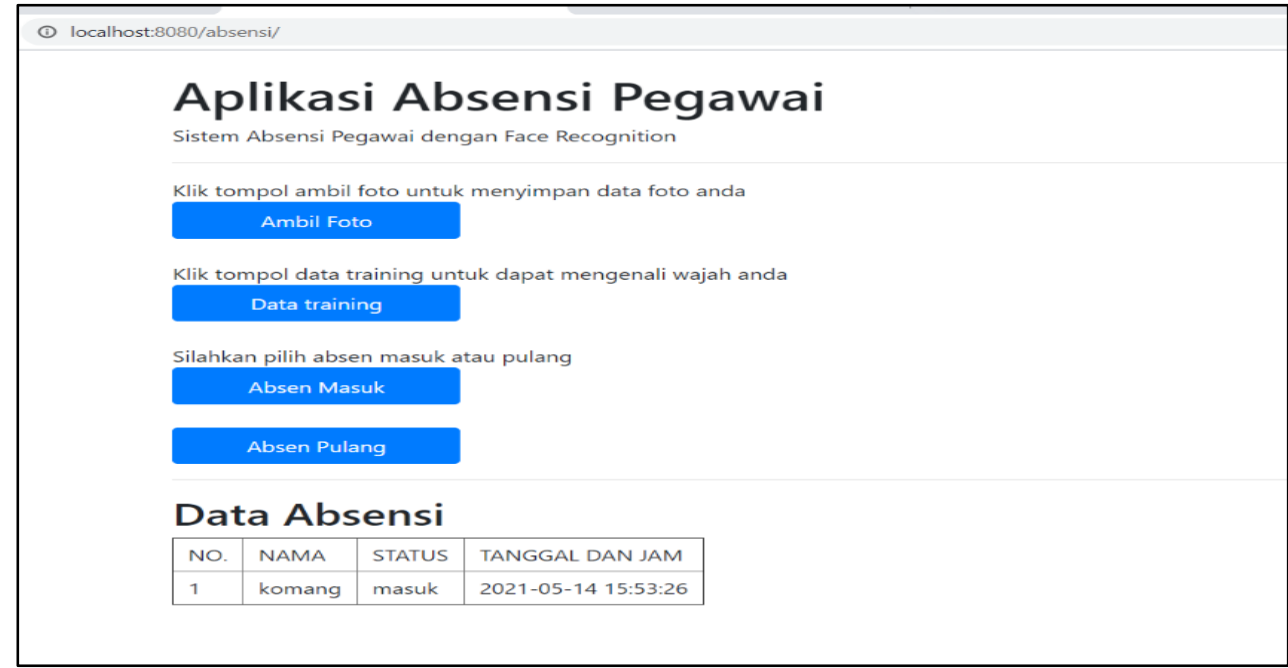

Gambar 11. Identitas user untuk data absensi

Hasil dari penelitian menggunakan beberapa parameter seperti berikut

a. Pengaruh jarak terhadap tingkat keberhasilan pengenalan wajah dan tersimpan ke database. Tabel 1 merupakan hasil ujicoba terhadap jarak untuk pengenalan wajah.

Tabel 1. Pengaruh jarak

\begin{tabular}{llll}
\hline No. Jarak & Hasil Mengenal Wajah & Tidak \\
\hline & $30 \mathrm{~cm}$ & \\
2 & $40 \mathrm{~cm}$ & \\
3 & $60 \mathrm{~cm}$ &
\end{tabular}


JURNAL MEDIA INFORMATIKA BUDIDARMA

Volume 5, Nomor 3, Juli 2021, Page 1008-1017

ISSN 2614-5278 (media cetak), ISSN 2548-8368 (media online)

Available Online at https://ejurnal.stmik-budidarma.ac.id/index.php/mib DOI 10.30865/mib.v5i3.3008

\begin{tabular}{|c|c|c|c|c|}
\hline \multirow[b]{2}{*}{ No. } & \multirow[b]{2}{*}{ Jarak } & \multirow[b]{2}{*}{ Hasil } & \multicolumn{2}{|c|}{ Mengenal Wajah } \\
\hline & & & $\mathrm{Ya}$ & Tidak \\
\hline 4 & $100 \mathrm{~cm}$ & & $\checkmark$ & \\
\hline 5 & $170 \mathrm{~cm}$ & & $\checkmark$ & \\
\hline 6 & $200 \mathrm{~cm}$ & & & $\checkmark$ \\
\hline
\end{tabular}

Dari tabel 1 terlihat bahwa jarak $30 \mathrm{~cm}$ tidak bisa mendeteksi wajah sama sekali. Jarak $40 \mathrm{~cm}$ sampai jarak $170 \mathrm{~cm}$ masih bisa mengenali wajah. Pada jarak 200 meter sudah tidak bisa mengenali wajah dengan dianggap belum terdaftar, akan tetapi masih dapat mendeteksi wajah.

b. Pengaruh kemiringan wajah terhadap tingkat keberhasilan pengenalan wajah dan tersimpan ke database. Tabel 2 merupakan hasil ujicoba terhadap kemiringan wajah untuk pengenalan wajah.

Tabel 2. Pengaruh kemiringan wajah

\begin{tabular}{|c|c|c|c|c|}
\hline & Drajat kemiringan & & \multicolumn{2}{|c|}{ Mengenal Wajah } \\
\hline No. & $\begin{array}{c}\text { dari tegak lurus } \\
\text { kekamera }\end{array}$ & Hasil & $\mathrm{Ya}$ & Tidak \\
\hline 1 & Tegak lurus & & $\checkmark$ & \\
\hline 2 & $\begin{array}{l}\text { Kurang lebih } 10^{\circ} \\
\text { kekanan }\end{array}$ & & $\checkmark$ & \\
\hline 3 & $\begin{array}{l}\text { Kurang lebih } 20^{\circ} \\
\text { kekanan }\end{array}$ & & $\checkmark$ & \\
\hline 4 & $\begin{array}{l}\text { Kurang lebih } 30^{\circ} \\
\text { kekanan }\end{array}$ & & & $\checkmark$ \\
\hline 5 & $\begin{array}{l}\text { Kurang lebih } 10^{\circ} \\
\text { keatas }\end{array}$ & & $\checkmark$ & \\
\hline
\end{tabular}

I Komang Setia Buana, Copyright @2021, MIB, Page 1015 
ISSN 2614-5278 (media cetak), ISSN 2548-8368 (media online)

Available Online at https://ejurnal.stmik-budidarma.ac.id/index.php/mib DOI 10.30865/mib.v5i3.3008

\begin{tabular}{cc} 
No. $\begin{array}{c}\text { Drajat kemiringan } \\
\text { dari tegak lurus } \\
\text { kekamera }\end{array}$ & \multicolumn{2}{c}{ Mengenal Wajah } \\
Ya & Tidak \\
6 & $\begin{array}{c}\text { Kurang lebih } 20^{\circ} \\
\text { keatas }\end{array}$ \\
& $\begin{array}{c}\text { Kurang lebih } 30^{\circ} \\
\text { keatas }\end{array}$
\end{tabular}

Tabel 2 memperlihatkan bahwa tingkat kemiringan mempengaruhi pengenalan wajah. Dalam ujicoba, penulis melakukan kemiringan wajah kekanan dan keatas. Keika tingkat kemiringan kurang lebih 30 derajat, wajah sudah tidak bisa dideteksi.

\section{KESIMPULAN}

Dari uraian di atas, dapat disimpulkan bahwa pendeteksian wajah menggunakan metode Viola Jones dan pengenalan wajah dengan algoritma LBPH berhasil dilakukan menggunakan bahasa pemrograman python. Keberhasilan pengenalan wajah dipengaruhi oleh jarak dan kemiringan wajah. Jarak terlalu dekat sekitar $30 \mathrm{~cm}$ dari kamera, wajah tidak bisa terdeteksi. Sebaliknya posisi wajah terlalu jauh kurang lebih $200 \mathrm{~cm}$, wajah masih bisa dideteksi akan tetapi tidak bisa dikenali. Untuk tingkat kemiringan wajah sekitar $20^{\circ}$ dari tegak lurus masih bisa dikenali, akan tetapi pada derajat kemiringan sekitar kurang lebih $30^{\circ}$ posisi keatas maupun kekanan, wajah tidak bisa dideteksi. Dari penelitian yang dilakukan data berhasil tersimpan ke database ketika wajah sudah dikenali.Bahasa pemrograman php bisa digunakan sebagai user interface yang akan memanggil skrip dari pemrograman python.

\section{REFERENCES}

[1] L. W. Alexander, S. R. Sentinuwo, A. M. Sambul, T. Informatika, U. Sam, and R. Manado, "Implementasi Algoritma Pengenalan Wajah Untuk Mendeteksi Visual Hacking," J. Tek. Inform., vol. 11, no. 1, 2017, doi: 10.35793/jti.11.1.2017.16969.

[2] A. Lazaro, J. L. Buliali, and B. Amaliah, "Deteksi Jenis Kendaraan di Jalan Menggunakan OpenCV,” J. Tek. ITS, vol. 6, no. 2, 2017, doi: 10.12962/j23373539.v6i2.23175.

[3] F. R. Ilhamullah and S. A. Yogyakarta, "Sistem Deteksi Wajah Dan Sebuah Benda Menggunakan Algoritma Viola-Jones Berbasis Open Cv Menggunakan Algoritma Viola-Jones Using Viola-Jones Algorithm Based Open Cv,” no. January, 2020.

[4] T. Paul, U. A. Shammi, and S. Kobashi, "A Study on Face Detection Using Viola-Jones Algorithm in Various Backgrounds, Angles and Distances," Int. J. Biomed. Soft Comput. Hum. Sci. Off. J. Biomed. Fuzzy Syst. Assoc., vol. 23, no. 1, pp. 27-36, 2018, doi: 10.24466/ijbschs.23.1_27.

[5] V. K. Sharma, "Designing of face recognition system," 2019 Int. Conf. Intell. Comput. Control Syst. ICCS 2019, no. Iciccs, pp. 459-461, 2019, doi: 10.1109/ICCS45141.2019.9065373.

[6] H. Simaremare and A. Kurniawan, "Perbandingan Akurasi Pengenalan Wajah Menggunakan Metode LBPH dan Eigenface dalam Mengenali Tiga Wajah Sekaligus secara Real-Time," J. Sains, Teknol. dan Ind., vol. 14, no. 1, pp. 6671,2016

[7] A. Fauzan, L. Novamizanti, and Y. N. Fuadah, "Perancangan Sistem Deteksi Wajah Untuk Presensi Kehadiran Menggunakan Metode LBPH ( Local Binary Pattern Histogram ) Berbasis Android," e-Proceeding Eng., vol. 5, no. 3, pp. 5403-5413, 2018.

[8] D. Kharat, P. Kajawe, S. Kopnar, N. Jinabade, and J. Wagh, "Face Recognition Using Local Binary Pattern Histogram ( LBPH )," Int. J. Innov. Res. Sci. Eng. Technol., vol. 2, no. 4, pp. 10659-10662, 2019, doi: 10.15680/IJIRSET.2019.0811013.

[9] P. R. Setiono, S. R. U. . Sompie, and M. E. . Najoan, “Aplikasi Pengenalan Wajah Untuk Sistem Absensi Kelas Berbasis Raspberry Pi," J. Tek. Inform., vol. 15, no. 3, pp. 179-188, 2020.

[10] M. Y. Florestiyanto, H. Himawan, and P. D. P. Silitonga, "Improved Viola-Jones Face Recognition UsingTracking," TEST Enginering Manaj., vol. 3, no. 3945, pp. 3945-3952, 2020.

[11] Mahmudi, M. Fatahillah, and Kusrini, "Implementasi Metode Viola Jones Untuk Mendeteksi Wajah Manusia,” J. Inf., $\begin{array}{lllllll}\text { vol. } 5, \quad \text { no. } & 1, & \text { pp. 2442-7942, 2019, [Online]. }\end{array}$ http://www.informa.poltekindonusa.ac.id/index.php/informa/article/view/69.

[12] F. Setiawan and D. A. R, "Sistem Pengenalan Wajah Dengan Metode Local Binary Pattern Histogram Pada Firebase," Semin. Nas. Teknol. Inf. dan Komun. STI\&K, vol. 4, no. September, pp. 1-7, 2020.

[13] W. Dwiparaswati, S. Kom, and S. V. Hilmawan, "Implementasi Face Recognition secara Real-time dengan Metode Haar Cascade Classifier menggunakan OpenCV-Python," 2017.

[14] A. Suharso, "Pengenalan Wajah Menggunakan Metode Viola-Jones dan Eigenface Dengan Variasi Posisi Wajah Berbasis 
JURNAL MEDIA INFORMATIKA BUDIDARMA

Volume 5, Nomor 3, Juli 2021, Page 1008-1017

ISSN 2614-5278 (media cetak), ISSN 2548-8368 (media online)

Available Online at https://ejurnal.stmik-budidarma.ac.id/index.php/mib

DOI 10.30865/mib.v5i3.3008

Webcam," Techno Xplore J. Ilmu Komput. dan Teknol. Inf., vol. 1, no. 2, pp. 19-30, 2017, doi: 10.36805/technoxplore.v1i2.107.

[15] K. Cen, "Study of Viola-Jones Real Time Face Detector," Ai2 (ALLEN Inst. ARTIFICAL Intell., vol. 9, no. 10, pp. 1-94, 2016.

[16] M. Khan, S. Chakraborty, R. Astya, and S. Khepra, "Face Detection and Recognition Using OpenCV," Proc. - 2019 Int. Conf. Comput. Commun. Intell. Syst. ICCCIS 2019, vol. 2019-Janua, pp. 116-119, 2019, doi: 10.1109/ICCCIS48478.2019.8974493.

[17] F. Deeba, A. Ahmed, H. Memon, F. A. Dharejo, and A. Ghaffar, "LBPH-based enhanced real-time face recognition," Int. J. Adv. Comput. Sci. Appl., vol. 10, no. 5, pp. 274-280, 2019, doi: 10.14569/ijacsa.2019.0100535.

[18] T. Dhawle, U. Ukey, and R. Choudante, "Face Detection and Recognition Using OpenCV and Python," Int. Res. J. Eng. Technol., vol. 07, no. 10, 2020. 